\title{
EFEKTIFITAS TEH DAUN KATUK TERHADAP PRODUKSI ASI PADA IBU POSTPARTUM HARI KE 4-7
}

\section{Effectiveness Of Katukuk Leaf Tea On Asi Production On Postpartum Mother Day 4-7}

\section{Sofia Mawaddah"*}

Novia Karlawaty ${ }^{2}$

1*2 Jurusan Kebidanan Politeknik Kesehatan Palangka Raya, Palangka Raya Kalimantan Tengah,Indonesia

\section{*email: sofizline@gmail.com}

\section{Kata Kunci: \\ Daun katuk \\ Produksi ASI \\ Ibu postpartum}

\section{Keywords:}

Katuk leaves

breast milk production

postpartum mothers

\begin{abstract}
Abstrak
Rendahnya cakupan ASI ekslusif merupakan tantangan bagi para bidan untuk lebih giat melakukan promosi kesehatan tentang pentingnya ASI ekslusif bagi pertumbuhan bayi. Rendahnya cakupan pemberian ASI ekslusif ini dapat berdampak pada kualitas hidup generasi penerus bangsa dan juga pada perekonomian nasional Salah satu upaya untuk meningkatkan laju sekresi dan produksi ASI adalah melalui penggunaan obat ramuan tradisional seperti teh daun katuk.Tujuan penelitian ini adalah untuk mengetahui efektifitas teh daun katuk terhadap produksi ASI pada ibu postpartum pada hari ke 47. Metode peneliian ini yaitu quasi eksperimental post test-only non equivalent control group design dengan jumlah sampel 30 ibu postpartum yang memenuhi kriteria inklusi. Uji statistik penelitian ini yaitu uji independen T-test. Hasil penelitian menunjukkan ada pengaruh pemberian teh daun katuk terhadap peningkatan produksi ASI pada ibu postpartum dengan nilai $P$-Value $=0,000(<0,05)$.
\end{abstract}

\begin{abstract}
The low coverage of exclusive breastfeeding is a challenge for midwives to be more active in promoting health about the importance of exclusive breastfeeding for infant growth. The low coverage of exclusive breastfeeding can have an impact on the quality of life for future generations of the nation and also on the national economy. One of the efforts to increase the rate of breast milk secretion and production is through the use of traditional herbal medicines such as katuk leaf tea. The aim of this study was to determine the effectiveness of katuk leaf tea. on milk production in postpartum mothers on day 4-7. This research method is a quasi experimental post-test-only non-equivalent control group design with a sample size of 30 postpartum mothers who meet the inclusion criteria. The statistical test of this study is the independent T-test. The results showed that there was an effect of giving katuk leaf tea on increasing breast milk production in postpartum mothers with a P-Value = $0.000(<0.05)$.
\end{abstract}

(C) year The Authors. Published by Institute for Research and Community Services Universitas Muhammadiyah Palangkaraya. This is Open Access article under the CC-BY-SA License (http://creativecommons.org/licenses/by-sa/4.0/). DOI: httDs://doi.org// 0.33084/ism.vxix.xxx.

\section{PENDAHULUAN}

Rendahnya cakupan ASI ekslusif merupakan tantangan bagi para bidan untuk lebih giat melakukan promosi kesehatan tentang pentingnya ASI ekslusif bagi pertumbuhan bayi. Rendahnya cakupan pemberian ASI ekslusuf ini dapat berdampak pada kualitas hidup generasi penerus bangsa dan juga pada perekonomian nasional (Permatasari, 2016).

Manfaat pemberian ASI menurut WHO melindungi bayi dari kuman, menyediakan nutrisi lengkap, jaminan asupan higienis dan aman, membuat bayi tumbuh sehat dan cerdas, mengurangi resiko kanker, membantu memberi jarak kelahiran, menghemat biaya (Anatolitou, 2012).
Banyak faktor yang menyebabkan ibu tidak memberikan ASI eksklusif kepada anak. Tingkat pendidikan ibu yang rendah, adanya kebudayaan setempat yang mempengaruhi, usia ibu, pekerjaan ibu, tidak adanya dukungan dari keluarga terdekat, kemudahan akibat kemajuan teknologi sehingga lebih memilih susu formula serta produksi ASI yang tidak lancar akibat ibu mengalami gizi kurang menjadi faktor yang mempengaruhi pemberian ASI eksklusif (Kusumaningrum, 2016).

ASI mengandung zat yang penting untuk tumbuh kembang bayi dan sesuai dengan kebutuhannya. Banyak hal yang dapat mempengaruhi produksi ASI. Produksi dan pengeluaran ASI dipengaruhi oleh dua hormon, 
yaitu prolaktin dan oksitosin. Prolaktin mempengaruhi jumlah produksi ASI, sedangkan oksitosin mempengaruhi proses pengeluaran ASI. Prolaktin berkaitan dengan nutrisi ibu, semakin asupan nutrisinya baik maka produksi yang dihasilkan juga banyak (Adinda, 2016).

Salah satu upaya yang dapat dilakukan untuk meningkatkan laju sekresi dan produksi ASI adalah melalui penggunaan obat ramuan tradisional seperti ektrak katuk (sauropus androgynus). Daun katuk (saoropus androgynus) ternyata mengandung hampir $7 \%$ protein dan $19 \%$ serat kasar, vitamin K, provitamin A,vitamin B dan C, mineral yang dikandung adalah kalsium (2,8\%) zat besi, kalium, fosfor dan magnesium(Juliastuti, 2019).

\section{METODOLOGI}

Desain penelitian ini yaitu Quasy Eksperiment atau eksperimen dengan post test-only non equivalent control group design. Penelitian ini dilakukan di Praktik Mandiri Bidan N dan Praktik Mandiri Bidan Y Palangka Raya pada bulan Desember 2019 - Februari 2020. Populasi dalam penelitian ini adalah semua ibu nifas pada bulan Juli-Oktober 2019 di PMB $N$ sebanyak 45 pasien dan PMB Y sebanyak 30 pasien dalam 3 bulan terakhir di Palangka Raya. Teknik pengambilan sampel menggunakan teknik purposive sampling dengan jumlah sampel sebanyak 30 responden yang memenuhi kriteria insklusi dan telah menandatangani surat pernyataan persetujuan selanjutnya akan diberikan perlakuan, kemudian setelah diberikan perlakuan sampel tersebut akan diobservasi kembali pada hari ke 7 untuk mengukur peningkatan produksi ASI pada ibu postpartum. Pada penelitian ini sampel dibagi menjadi 2 kelompok yaitu kelompok intervensi diberikan perlakuan teh daun katuk, sedangkan kelompok control tidak diberikan teh daun katuk, responden mengkonsumsi vitamin bagi ibu menyusui. Penelitian ini telah dilakukan uji layak etik di Komisi Penelitian
Kesehatan Poltekkes Kemenkes Palangka Raya dengan nomor :085/IV/KE.PE/2020.

\section{HASIL DAN PEMBAHASAN}

Tabel I. Distribusi Frekuensi Responden Berdasarkan Usia Dan Paritas

\begin{tabular}{l|c|c}
\hline Variabel & $\begin{array}{c}\text { Frekuensi } \\
\text { (n) }\end{array}$ & Persentase (\%) \\
\hline Umur & 14 & 42 \\
$<20$ tahun & 8 & 24 \\
$20-30$ & 8 & 24 \\
tahun & & 100 \\
$>30$ tahun & 30 & 27 \\
\hline Total & 9 & 63 \\
\hline Paritas & 21 & 100 \\
Primipara & 30 &
\end{tabular}

Berdasarkan tabel I menunjukkan responden terbanyak berumur $<20$ tahun yaitu 14 responden (42\%), sementara untuk paritas yang terbanyak yaitu multipara berjumlah 21 responden (63\%).

\begin{tabular}{|c|c|c|c|c|c|c|}
\hline \multicolumn{7}{|c|}{$\begin{array}{c}\text { Tabel II. Beda Rata-Rata Berat Badan Lahir Bayi dan } \\
\text { Produksi ASI }\end{array}$} \\
\hline \multirow[t]{2}{*}{ Kelompok } & \multicolumn{3}{|c|}{ Berat Badan Lahir } & \multicolumn{3}{|c|}{ Produksi ASI } \\
\hline & Mean & SD & $\begin{array}{l}\text { Min- } \\
\text { Max }\end{array}$ & Mean & SD & $\begin{array}{l}\text { Min- } \\
\text { Max }\end{array}$ \\
\hline $\begin{array}{l}\text { Teh daun } \\
\text { katuk }\end{array}$ & $3233, .33$ & 388.526 & $\begin{array}{l}2500- \\
3800\end{array}$ & 3540,00 & 392,428 & $\begin{array}{l}2800- \\
42000\end{array}$ \\
\hline $\begin{array}{l}\text { Vitamin ibu } \\
\text { menyusui }\end{array}$ & 2980,00 & 332.093 & $\begin{array}{l}2500- \\
3500\end{array}$ & 2993,33 & 317,280 & $\begin{array}{l}2500- \\
3600\end{array}$ \\
\hline
\end{tabular}

Berdasarkan tabel II menunjukkan rata-rata berat badan lahir pada kelompok teh daun katuk yaitu 3233,33 gram, sementara pada kelompok vitamin ibu menyusui rata-rata berat badan lahir yaitu 2980,00 .

Tabel III. Uji Independen Sampel T Test Rata-Rata Produksi ASI

\begin{tabular}{lcccc|ccc}
\multicolumn{8}{c}{ Produksi ASI } \\
\hline Produksi ASI & $\begin{array}{c}\text { Mean } \\
(\mathbf{g r})\end{array}$ & SD & SE & Lower & Upper & Min-Ma) & P-valut \\
& 3540.0( & 392.428 & 101.325 & & & $24-100$ & \\
\hline $\begin{array}{l}\text { Teh daun } \\
\text { katuk }\end{array}$ & & & & 279.76 & 813.572 & $53-100$ & 0,000 \\
\hline $\begin{array}{l}\text { Vitamin ibu } \\
\text { menyusui }\end{array}$ & $2993.3:$ & 317.280 & 81.921 & & & & \\
\hline $\begin{array}{l}\text { Berdasarkan } \\
\text { herdasil }\end{array}$ & uji & statistic & pada & tabel & III
\end{tabular}
menggunakan uji Independen $t$ test terdapat perbedaan rata-rata berat badan bayi kelompok intervensi dan kelompok kontrol sebesar 546.667. Standar error difference adalah 19.404 Nilai lower dan upper adalah 279.762 dan 813.572. Pada hasil berat badan bayi kelompok kontrol minimal dan maksimal adalah 2500 gram dan 3600 gram. Sedangkan pada berat badan bayi kelompok intervensi minimal dan maksimal adalah 2800gram dan 4200 
gram. Dapat diketahui bahwa $\mathrm{P}$-value tersebut lebih kecil dari $\alpha(0,05)$ yaitu sebesar 0,000 , sehingga dapat disimpulkan bahwa ekstrak teh daun katuk efektif terhadap peningkatan produksi ASI pada ibu postpartum.

Berdasarkan tabel independen $t$ test diatas SD intervensi 392.428 sedangkan kelompok kontrol 317.280 terdapat perbedaan 75.148 , nilai SD menjauhi nilai 0 berarti data sample semakin menyebar (bervariasi) dari rata-rata,sebaliknya semakin kecil SD mendekati 0 maka data sample semakin homogen.

SE intervensi I0I.325 sedangkan SE kelompok kontrol 8I.92I terdapat perbedaan 10.404 berarti data sample semakin representatif (mewakili) untuk dijadikan sample penelitian sehingga semakin kecil SE maka sample lebih akurat. Diketahui nilai mean difference adalah sebesar 546.667. Nilai ini selisih nilai rata-rata produksi ASI pada kelompok intervensi dengan ratarata produksi ASI pada kelompok kontrol atau 3540.00-2993.33 = 546.667yang artinya kelompok intervensi lebih efektif meningkatkan produksi ASI pada ibu postpartum dan rentang selisih produksi ASI pada kelompok intervensi dan kelompok kontrol tersebut adalah 279.762 sampai $813.572 \quad(95 \%$ Confindence Interval of the Difference Lower Upper) dengan standar error difference adalah selisih deviasi antara kelompok intervensi dan kelompok kontrol $|0| .325-8|.92|=\mid 9.404$.

Hasil pengukuran produksi ASI dengan kenaikan berat badan pada bayi sebelum dan sesudah pada kelompok kontrol yaitu mengalami penurunan berat badan sebanyak 4 orang (16,7\%) ditimbang pada hari ke 7 . Ibu yang mengalami masalah dalam menyusui dengan usia muda dan baru pertama kali melahirkan sehingga ibu kurang mengetahui cara menyusui dan faktor faktor yang mempengaruhi ASI. Setiap hari peneliti melakukan recall terhadap responden dalam hal mengkonsumsi ekstrak teh daun katuk. Bayi yang mengalami penurunan berat badan disebabkan kurangnya ASI si ibu sehingga si bayi tidak merasa cukup. Walaupun sebagian ibu yang mengalami masalah ASI tetapi mereka tetap memberikan ASI eksklusif, sedangkan pada kelompok intervensi mengalami peningkatan berat badan sebanyak 15 orang (100\%). Ketika peneliti mengunjungi responden untuk menanyakan apakah ada efek ekstrak teh daun katuk terhadap tubuh ternyata tidak ada efek samping karena sesuai dengan dosis. Pada awal melakukan penelitian, peneliti mengacu pada berat badan bayi pada saat baru lahir dan melakukan observasi. Pada hari ke 7 kemudian dilakukan kunjungan dengan menimbang berat badan bayi apakah ada kenaikan atau efek sampingdari pemberian ekstrak teh daun katuk yang diberikan pada ibu.

Menurut peneliti sebelumnya menjelaskan ada beberapa ibu menyusui mengalami gangguan terhadap produksi ASI. Kandungan dari alkaloid dan strerol yang terkandung di dalam daun katuk dapat meningkatkan produksi ASI. Sehingga kebutuhan ASI yang akan diberikan terhadap bayi pada periode menyusui dapat terpenuhi(Aulianova, 2016).

Masalah kesehatan merupakan salah satu aspek penting yang harus diperhatikan, salah satunya adalah pemberian ASI eksklusif pada bayi. Dengan memberikan ASI eksklusif pada bayi dapat memberikan pertahanan tubuh yang kuat dibandingkan dengan yang tidak mendapatkan ASI, selain itu ASI juga membentuk jaringan otak karena mengandung omega 3 untuk pematangan sel-sel otak (Asifah,2017).

Faktor-faktor yang mempengaruhi produksi ASI adalah makanan ibu. Makanan Makanan yang dimakan seorang ibu yang sedang menyusui tidak secara langsung mempengaruhi mutu ataupun jumlah air susu yang dihasilkan. Unsur gizi dalam I liter ASI setara dengan unsur gizi yang terdapat dalam 2 piring nasi ditambah I butir telur. Jadi, diperlukan energi yang sama dengan jumlah energi yang diberikan I piring nasi untuk membuat I liter. Apabila ibu yang sedang menyusui bayinya tidak mendapatkan tambahan 
makanan maka akan terjadi kemunduran dalam produksi ASI (Khasanah, 2013).

Hasil penelitian ini juga sejalan dengan Penelitian Suprayogi et al. (2015) tentang pengaruh daun katuk pada peningkatan produksi ASI telah banyak dilakukan. Hasil menunjukkan respon positif pada peningkatan produksi susu secara nyata pada semua dosis pemberian dibandingkan dengan kelompok kontrol, dengan persentasi peningkatan secara berurutan adalah 35, 40 dan 34\%. Kemungkinan hal ini karena senyawa aktif non - polar dalam Katuk peran penting dalam aksi hormonal dan metabolik di kelenjer ASI.

Selain itu, Akbar et.al (2019) melakukan penelitian untuk melihat pengaruh pemberian tepung daun katuk terhadap produksi air susu ibu postpartum selama 3 minggu awal masa postpartum. Hasil penelitian menunjukan bahwa penambahan daun katuk dapat meningkatkan produksi ASI dan BB anak selama 3 minggu perlakuan tetapi tidak mempengaruhi mortalitas anak dan respon imun. Suprayogi et.al (20I4) melakukan penelitian tentang fraksi daun katuk sebagai obat untuk memperbaiki produksi ASI. Hasil penelitian ini memberikan respon positif terhadap total produksi ASI selama 10 hari laktasi. dikemukakan keberadaan senyawa - senyawa aktif dalam daun katuk, yang merupakan prekursor hormon progesteron dan estrogen.

\section{KESIMPULAN}

ASI merupakan makanan yang baik bagi bayi karena banyak mengandung zat gizi dan bisa memberikan daya imunitas secara alami. Beberapa ramuan tradisional bisa membantu memperlancar keluarnya ASI. Untuk itu, perlu makanan seimbang dengan prinsip yang sama dengan makanan ibu hamil, tetapi jumlahnya lebih banyak dan gizi lebih baik. Jika produksi ASI kurang baik, makanan yang dianjurkan untuk dikonsumsi, banyak obat-obatan tradisional yang ditawarkan kepada mereka untuk mengurangi keluhan tersebut, salah satunya adalah ekstrak daun katuk, yang dapat menambah produksi dengan cara diolah menjadi teh daun katuk.

\section{UCAPAN TERIMA KASIH}

Peneliti berterima kasih kepada Praktik Mandiri Bidan N dan Praktik Mandiri Bidan Y di Kota Palangka Raya yang telah memfasilitasi dan membantu peneliti dari awal pengambilan data sampai penelitian ini selesai dilakukan. Peneliti juga berterima kasih pada ibu-ibu postpartum yang telah bersedia menjadi responden pada penelitian ini.

\section{REFERENSI}

I. Permatasari, I. \& D. A. \& F. R. (20|6). Analisis Pengetahuan dan Perilaku lbu Bekerja Seputar Manajemen Laktasi. Seminar Dan Workshop Nasional Keperawatan, 173-177.

2. Anatolitou, F. (20/2). Human milk benefits and breastfeeding. Journal of Pediatric and Neonatal Individualized Medicine, I(I), II-I8. https://doi.org/10.7363/010113

3. Kusumaningrum, T. (2016). Gambaran FaktorFaktor Ibu yang Tidak Memberikan ASI Eksklusif di Desa Cepokosawit Kabupaten Boyolali.

4. Adinda, F. (20I6). Peran ASI Bagi Tumbuh Kembang Anak. World Breastfeeding Week.

5. Juliastuti. (2019). Efektivitas Daun Katuk (Sauropus androgynus) Terhadap Kecukupan ASI pada lbu Menyusui di Puskesmas Kuta Baro Aceh Besar. Indonesian Journal for Health Sciences, 3(I), I-5.

6. Aulianova, R. S. dan T. (20I6). Efektivitas Ekstraksi Alkaloid dan Sterol Daun Katuk (Sauropus androgynus) terhadap Produksi ASI. Jurnal Majority, 5(I), II7-I2I.

7. Asifah, F. (20I7). Peran Asi bagi Tumbuh Kembang Anak. World Breastfeeding Week. Jakarta

8. Khasanah, A. 20I3. Faktor Ibu yang Berhubungan dengan Praktik Pemberian Asi Eksklusif di Wilayah 
Kerja Puskesmas Pamotan. Skripsi.

9. Suprayogi, A., Kusumorini, N., Arita, S.E.D. (20I5). Hexane Fraction of Sauropus Androgynus Leaves As A Medicine For Improving Milk Yield, The Performance of Female and Rat Pus. Jurnal Veteriner Maret 2015.

10. Akbar, N., Fitria, F., \& Putri, R. D. (20|9). FaktorFaktor Yang Berhubungan Dengan Pemberian Asi Eksklusif Di Puskesmas Kalirejo Kabupaten Pesawaran Tahun 2019.Jurnal Kebidanan Malahayati, 5(4), 309-316.

II. Suprayogi, A., Latif, H., Yudi., Ruhyana, A., 2014. Peningkatan produksi susu sapi perah di peternakan rakyat melalui pemberian katuk-ipb3 sebagai aditif pakan. Jurnal IImu Pertanian Indonesia. 18(3): |40-|43 